\title{
PERKEMBANGAN PENGATURAN JAMINAN SOSIAL TENAGA KERJA DALAM RANGKA PERLINDUNGAN HUKUM BURUH/PEKERJA
}

\author{
Dede Agus \\ Fakultas Hukum Universitas Sultan Ageng Tirtayasa, Serang-Banten, \\ e-mail: agusdede92@yahoo.co.id
}

\begin{abstract}
Each worker/workers face the risks of social-economic and social security can cope with the risks of the socio-economic. Setting social security law for labors has been started since the days of the Dutch East Indies colonial rule until the time of independence of the Republic of Indonesia both early era of independence as well as in the reform era. Therefore, this paper intends to study the development of legal regulation of social security. Social security arrangements colonial era the Netherlands East Indies, set in the Civil Code and Regulations Accident or Ongevallen-Regelling 1939, but the laborers / workers unprotected. New on the independence of the Republic of Indonesia, especially after the enactment of legislation in the field of social security such as: Law Number 3 of 1992 on Social Security of Labor, Law 20 of 2004 on National Social Security System and the Law 24 of 2011 on Social Security Organizing Body, laborers / workers obtain legal protection in the field of social security, which programnyapun not only guarantees compensation for workplace accidents alone, but includes work accident insurance program, program life insurance, security program today old, pension insurance programs, and health care insurance program.
\end{abstract}

Keywords: Social Security Labor Protection Law, the Labour / Workers, Development, Settings.

abstrak
Setiap buruh/pekerja menghadapi resiko-resiko sosial-ekonomis dan jaminan
sosial tenaga kerja dapat mengatasi resiko-resiko sosial-ekonomis tersebut.
Pengaturan hukum jaminan sosial tenaga kerja telah di mulai sejak zaman
penjajahan pemerintahan Hindia Belanda sampai zaman kemerdekaan
Republik Indonesia baik era awal kemerdekaan maupun di era reformasi.
Oleh karena itu, tulisan ini bermaksud mengkaji perkembangan pengaturan
hukum jaminan sosial tenaga kerja. Pengaturan jaminan sosial tenaga kerja
zaman penjajahan pemerintahan Hindia Belanda, di atur dalam KUH Perdata
dan Peraturan Kecelakaan atau Ongevallen-Regelling 1939, tetapi
buruh/pekerja tidak terlindungi. Baru pada masa kemerdekaan Republik
Indonesia terutama setelah diberlakukannya peraturan perundangan dibidang 
jaminan sosial tenaga kerja seperti : UU No. 3 Tahun 1992 tentang Jaminan Sosial Tenaga Kerja, UU No. 20 Tahun 2004 tentang Sistem Jaminan Sosial Nasional dan UU No. 24 Tahun 2011 tentang Badan Penyelenggara Jaminan Sosial, buruh/pekerja memperoleh jaminan perlindungan hukum di bidang jaminan sosial tenaga kerja, yang programnyapun tidak hanya jaminan gantirugi karena kecelakaan kerja saja, tetapi meliputi program jaminan kecelakaan kerja, program jaminan kematian, program jaminan hari tua, program jaminan pension, dan program jaminan pemeliharaan kesehatan.

Kata kunci: Jaminan Sosial Tenaga Kerja, Perlindungan Hukum, Buruh/Pekerja, Perkembangan, Pengaturan.

\section{A. Pendahuluan}

Manusia dalam hidupnya menghadapi ketidakpastian, baik ketidakpastian yang sifatnya spekulasi maupun ketidakpastian murni yang selalu menimbulkan kerugian. Ketidakpastian yang sifatnya murni disebut dengan resiko. Resiko terdapat dalam berbagai bidang, dan dapat digolongkan dalam dua kelompok utama, yaitu resiko fundamental dan resiko khusus. Resiko fundamental bersifat kolektif dan dirasakan oleh seluruh masyarakat, seperti resiko politis, sosial-ekonomis, hankam, dan internasional. Resiko khusus lebih bersifat individual karena dirasakan oleh perorangan, seperti resiko terhadap harta benda, resiko terhadap diri pribadi, dan resiko terhadap kegagalan usaha ${ }^{1}$. Begitu pula buruh/pekerja menghadapi resiko-resiko. Setiap buruh/pekerja dan juga setiap orang pasti pada suatu saat akan mencapai hari tua. Produktivitas kerja suatu saat akan menurun, sehingga perlu diganti dengan buruh/pekerja yang lebih muda, dengan demikian, buruh/pekerja tersebut akan diberhentikan dari pekerjaannya, yang tentu hal ini membawa akibat penghasilannya berhenti pula. Seorang buruh/pekerja juga dapat pula mengalami kecelakaan kerja sehingga dapat mengganggu kelancaran penerimaan penghasilannya. Buruh/pekerja juga dapat menderita sakit mulai dari yang ringan sampai yang berat dan harus dirawat di rumah sakit, perawatan itu memerlukan pembiayaan yang akan memberatkan gaji atau upahnya. Terlebih apabila seorang buruh/pekerja sebagai pencari nafkah meninggal dunia, dan penghasilannya dihentikan, maka keluarga yang ditinggalkan akan kehilangan sumber penghasilannya.

Oleh karena resiko-resiko di atas selalu dihadapi oleh setiap buruh/pekerja dan bersifat universal, maka diperlukan suatu instrumen atau alat yang dapat menanggulangi atau setidak-tidaknya dapat mencegah atau

${ }^{1}$ Zainal Asikin dk, Dasar-dasar Hukum Perburuhan, (Jakarta: RadjaGrafindo Persada, 2006), hlm. 77. 
mengurangi timbulnya resiko-resiko yang dialami oleh buruh/pekerja. Instrumen atau alat yang ampuh dan tepat untuk menanggulangi resikoresiko sosial-ekonomis disebut dengan jaminan sosial. Penjelasan Umum Undang-Undang Nomor 3 Tahun 1992 tentang Jaminan Sosial Tenaga Kerja menyatakan : ${ }^{2}$

Pada hakikatnya program jaminan sosial tenaga kerja ini memberikan kepastian berlangsungnya arus penerimaan penghasilan keluarga sebagai pengganti sebagian atau seluruh penghasilan yang hilang. Jaminan sosial tenaga kerja mempunyai beberapa aspek, antara lain:

a. memberikan perlindungan dasar untuk memenuhi kebutuhan hidup minimal bagi tenaga kerja beserta keluarganya; dan

b. merupakan penghargaan kepada tenaga kerja yang telah menyumbangkan tenaga dan pikirannya kepada perusahaan tempat mereka bekerja.

Jaminan sosial merupakan hak dari buruh/pekerja untuk mendapatkan perlindungan dan merupakan kewajiban dari pengusaha untuk memberikan perlindungan kepada buruh/pekerja. Bahkan hak atas jaminan sosial di dunia internasional merupakan hak asasi manusia yang tercantum dalam Deklarasi Hak-Hak Asasi Manusia Perserikatan Bangsa Bangsa (PBB), dimana disebutkan bahwa setiap orang berhak atas perlindungan dan jaminan pada waktu mengalami sakit, cacat, hari tua, meninggal dunia, dan menganggur. Oleh karena itu, ILO (International Labour Organization) dalam Konvensi Nomor 102 Tahun 1952 tentang Standar Minimum Jaminan Sosial menyebutkan setidak-tidaknya tiga dari sembilan cabang program jaminan sosial yang secara minimum harus diberikan kepada buruh/pekerja, yaitu jaminan hari tua, jaminan kecelakaan kerja, dan jaminan pemeliharaan kesehatan ${ }^{3}$.

Di lingkup nasional, hak atas jaminan sosial tersirat di dalam Pasal 27 ayat (2) dan Pasal 28 H ayat (3) perubahan kedua UUD 1945. Pasal 27 ayat (2) merumuskan bahwa: "Tiap-tiap warga negara berhak atas pekerjaan dan penghidupan yang layak bagi kemanusiaan", sedangkan Pasal $28 \mathrm{H}$ ayat (3) perubahan kedua UUD 1945 merumuskan: "Setiap orang berhak atas

\footnotetext{
${ }^{2}$ Undang-undang Nomor 3 Tahun 1992 tentang Jaminan Sosial Tenaga Kerja masih tetap berlaku meskipun telah berlaku Undang-undang No. 40 Tahun 2004 tentang Sistem Jaminan Sosial Nasional (SJSN) dan Undang-undang Nomor 24 Tahun 2011 tentang Badan Penyelenggara Jaminan Sosial (BPJS). Pada saat mulai beroperasinya BPJS Ketenagakerjaan menyelenggarakan program jaminan kecelakaan kerja, jaminan hari tua, jaminan pensiun, dan jaminan kematian (paling lambat 1 Juli 2015), Undang-undang No. 3 Tahun 1992 tentang Jaminan Sosial Tenaga Kerja dicabut dan dinyatakan tidak berlaku lagi (Pasal 69 UU No. 24 Tahun 2011).

${ }^{3}$ Keterangan Pemerintah Atas RUU Nomor 3 Tahun 1992 tentang Jaminan Sosial Tenaga Kerja.
} 
jaminan sosial yang memungkinkan pengembangan dirinya secara utuh sebagai manusia yang bermartabat". Oleh karena penghidupan yang layak dan jaminan sosial merupakan hak tiap warga negara, khusus di bidang jaminan sosial tenaga kerja, maka peraturan pelaksanaan lebih lanjut dari Pasal 27 ayat (2) UUD 1945 telah terbentuk, yaitu Undang-Undang Nomor 3 Tahun 1992 tentang Jaminan Sosial Tenaga Kerja beserta peraturan pelaksanaan lainnya. Menurut Undang-Undang No. 3 Tahun 1992, jaminan sosial tenaga kerja adalah suatu perlindungan bagi tenaga tenaga kerja dalam bentuk santunan berupa uang sebagai pengganti sebagian dari penghasilan yang hilang atau berkurang dan pelayanan sebagai akibat peristiwa atau keadaan yang dialami oleh tenaga kerja berupa kecelakaan kerja, sakit, hamil, bersalin, hari tua, dan meninggal dunia (Pasal 1 angka 1).

Sebagaimana telah disebutkan di atas bahwa jaminan sosial tenaga kerja sebagai alat yang ampuh dan tepat bagi perlindungan buruh/pekerja dalam menanggulangi resiko-resiko sosial-ekonomis maka pengaturannya pun telah mengalami perkembangan yang panjang dari masa ke masa, yaitu dimulai dari zaman penjajahan pemerintahan Hindia Belanda sampai zaman kemerdekaan Republik Indonesia baik era awal kemerdekaan maupun diera reformasi. Meskipun sekarang telah memperoleh dasar hukum pengaturan yang kuat melalui Undang-Undang No. 3 Tahun 1992 tentang Jaminan Sosial Tenaga Kerja beserta peraturan pelaksanaannya, namun tidak lepas dari sejarah perkembangannya, bahkan sekarang telah berlaku pula Undangundang Sistem Jaminan Sosial Nasional (Undang-Undang No. 40 Tahun 2004) dan Undang-Undang Nomor 24 Tahun 2011 tentang Badan Penyelenggara Jaminan Sosial (BPJS) sebagai peraturan pelaksanaan dari Undang-undang No. 40 Tahun 2004. Oleh karena itu, perlu dikaji perkembangan pengaturan jaminan sosial tenaga kerja dalam rangka perlindungan buruh/pekerja, dan dengan demikian tulisan ini akan membahas atau mengkaji perkembangan pengaturan jaminan sosial tenaga kerja dalam rangka perlindungan buruh/pekerja.

\section{B. Pembahasan}

\section{Perkembangan Pengaturan Jaminan Sosial Tenaga Kerja pada Zaman Penjajahan Pemerintahan Hindia Belanda}

Dasar hukum pengaturan jaminan sosial tenaga kerja pada zaman penjajahan pemerintahan Hindia Belanda adalah Kitab Undang-undang Hukum Perdata (KUH Perdata) yang sudah dinyatakan berlaku di Hindia Belanda sejak tanggal 1 Mei 1848, dan disusul kemudian dengan keluarnya Peraturan Kecelakaan atau Ongevallen-Regelling tahun 1939.

Dalam KUH Perdata jaminan sosial tenaga kerja akibat dari adanya kewajiban majikan (pengusaha) untuk mengatur tempat kerja, alat-alat kerja serta memberikan petunjuk tentang cara-cara dan sikap yang aman dalam 
melakukan pekerjaan, agar buruh/pekerja terhindar dari kecelakaan kerja. Kewajiban ini telah digariskan di dalam Pasal 1602 w ayat (1) KUH Perdata, yaitu :

Si majikan diwajibkan untuk mengatur dan memelihara ruanganruangan, piranti-piranti atau perkakas-perkakas dalam mana atau dengan mana ia menyuruh melakukan pekerjaan sedemikian rupa, begitu pula untuk mengenai hal melakukannya pekerjaan mengadakan aturan yang sedemikian serta memberikan petunjukpetunjuk, hingga si buruh diperlindungi terhadap bahaya bagi jiwa, kehormatan, dan harta bendanya, sebegitu jauh, sebagaimana dapat dituntut sepantasnya berhubung dengan sifat pekerjaan.

Meskipun pengusaha telah melaksanakan kewajibannya untuk mengatur tempat kerja dan alat-alat kerja serta memberi petunjuk tentang cara-cara sikap yang aman untuk melakukan kerja, dan begitu pula buruh/pekerja telah menaati segala peraturan keselamatan kerja, resiko kecelakaan kerja kemungkinan besar bisa terjadi. Hal ini disebabkan oleh semakin meningkatnya penggunaan teknologi diberbagai sektor kegiatan usaha, sehingga dapat mengakibatkan semakin tingginya resiko yang mengancam keselamatan, kesehatan dan kesejahteraan buruh/pekerja. Oleh karena itu, pengusaha wajib melindungi buruh dari kemungkinan tertimpa resiko kecelakaan kerja.

Pertama kali perlindungan bagi buruh yang mengalami kecelakaan kerja yang diakibatkan dari kelalaian pengusaha untuk mengatur tempat kerja dan alat-alat kerja serta memberi petunjuk tentang cara-cara sikap yang aman untuk melakukan kerja adalah diatur oleh Pasal 1602 w ayat (2) dan (3) KUH Perdata, yaitu :

Jika kewajiban-kewajiban itu tidak terpenuhi, si majikan diwajibkan mengganti kerugian yang karenanya menimpa si buruh dalam menjalankan pekerjaannya, kecuali apabila ia dapat membuktikan bahwa tidak terpenuhinya kewajiban-kewajiban itu disebabkan karena keadaan memaksa atau bahwa kerugian tersebut sebagian besar ada juga disebabkan oleh kesalahan kasar dari si buruh sendiri.

Jika sebagai akibat dari tidak terpenuhinya kewajiban-kewajiban itu oleh si majikan, si buruh di dalam melakukan pekerjaannya mendapat luka yang sedemikian hingga ia meninggal dunia karenanya, maka si majikan diwajibkan memberikan ganti-rugi kepada suami atau isteri si buruh yang ditinggalkan, anak-anak, atau orang tua si meninggal, yang lazimnya dipelihara dengan pekerjaannya, kecuali apabila si majikan itu dapat membuktikan, bahwa tidak terpenuhinya kewajiban-kewajiban itu disebabkan karena keadaan memaksa atau bahwa meninggalnya si buruh itu 
sebagian besar ada juga disebabkan oleh kesalahan kasar dari si buruh sendiri

Isi pokok pasal tersebut menyatakan bahwa buruh/pekerja yang hendak meminta ganti kerugian karena kecelakaan kerja, harus terlebih dahulu membuktikan ada tidaknya unsur kesalahan pada pihak pengusaha. Jika diakibatkan oleh kelalaian pengusaha maka buruh akan mendapat ganti kerugian, dan sebaliknya jika tidak terbukti maka buruh/pekerja tidak mendapat ganti kerugian. Dengan demikian perlindungan buruh/pekerja melalui Pasal 1602 w KUH Perdata tidak terlindungi mengingat sulitnya membuktikan unsur kesalahan. Berkaitan dengan ini Zainal Asikin dkk berpendapat bahwa : ${ }^{4}$

Ketentuan Pasal 1602 w KUH Perdata tidak mungkin dapat dilaksanakan karena :

1. buruh kebanyakan berpendidikan minim, sehingga tidak/belum mengenal bagaimana beracara di pengadilan;

2. biaya beracara di pengadilan relatif cukup besar;

3. sulit untuk mendapatkan saksi dari rekan sekerja guna membuktikan kelalaian majikan (pengusaha : kursif penulis), karena rekan-rekannya tentu saja tak akan mau terlibat, takut dipecat oleh pengusaha; dan

4. kalaupun buruh nekad menuntut, akan menimbulkan keretakan pada hubungan kerjanya dengan pengusaha.

Dalam rangka melindungi buruh/pekerja yang mendapat kecelakaan kerja, maka unsur kesalahan dilepaskan dan ganti rugi karena kecelakaan didasarkan atas tanggung jawab pengusaha yang terjadi di perusahaannya. Pemberian ganti rugi dipandang sebagai resiko menjalankan perusahaan (resque professional) yang berarti apabila buruh mengalami kecelakaan berhubung dengan hubungan kerja tidak perlu lagi membuktikan ada tidaknya unsur kesalahan pihak pengusaha, tetapi begitu terjadi kecelakaan kerja menjadi tanggungjawab pengusaha ${ }^{5}$. Dengan demikian, menggunakan Peraturan Kecelakaan atau Ongevallen-Regelling tahun 1939. Kecelakaan kerja menurut peraturan ini adalah kecelakaan jasmani dan dikaitkan dengan kerja di perusahaan. Tentang Peraturan Kecelakaan atau OngevallenRegelling F.X. Djumialdji berpendapat :

Dengan adanya Ongevallen-Regelling 1939 ini buruh sudah agak mendapat perlindungan sebab menurut Ongevallen-Regelling tanggungjawab segala kecelakaan yang terjadi dalam kerja di perusahaan diletakkan pada perusahaan, tanpa memperhatikan apakah kecelakaan tadi disebabkan karena kebetulan atau sebab

\footnotetext{
${ }^{4}$ Zainal Asikin dk, Op.cit.., hlm. 82.

${ }^{5}$ Iman Soepomo, Pengantar Hukum Perburuhan, (Jakarta: Djambatan, 2003), hlm. 140.
} 
keadaan (overmacht) atau karena kesalahan atau karena kekurangan-kekurangan dari pihak majikan atau karena kesalahan pihak buruh. Hanya dalam hal buruh dengan sengaja menyebabkan terjadinya kecelakaan kerja, tanggung jawab tidak diletakan pada majikan ${ }^{6}$.

Jika pada waktu berlakunya Pasal 1602 w KUH Perdata buruh/pekerja sama sekali tidak mendapat perlindungan apabila mengalami kecelakaan kerja, maka dengan berlakunya Peraturan Kecelakaan atau OngevallenRegelling 1939, buruh/pekerja sudah agak mendapatkan perlindungan bila mengalami kecelakaan kerja. Tetapi Ongevallen-Regelling ini pun mengandung kelemahan, sebab yang dikategorikan kecelakaan kerja adalah kecelakaan jasmani dan dikaitkan dengan kerja di perusahaan. Sedangkan kecelakaan kerja mungkin saja ditimbulkan oleh penyakit yang timbul karena hubungan kerja dan kecelakaan kerja tidak hanya dikaitkan dengan kerja di perusahaan, tetapi kecelakaan kerja berhubungan dengan hubungan kerja.

\section{Perkembangan Pengaturan Jaminan Sosial Tenaga Kerja pada Zaman Kemerdekaan Negara Republik Indonesia}

Pada masa kemerdekaan Republik Indonesia pengaturan jaminan sosial tenaga kerja terus mengalami pergeseran (perubahan). Hal ini mengingat pengaturan-pengaturan sebelumnya baik dalam KUH Perdata maupun Peraturan Kecelakaan atau Ongevallen-Regelling tahun 1939 belum memberikan jaminan perlindungan hukum bagi buruh/pekerja di bidang jaminan sosial tenaga kerja. Oleh karena itu, pada awal kemerdekaan Ongevallen-Regelling 1939, pada tahun 1947 diganti oleh Undang-undang Kecelakaan No. 33 Tahun 1947, dan dinyatakan berlaku bagi seluruh Indonesia oleh Undang-undang No. 2 Tahun 1951. Tentang pernyataan berlakunya undang-undang No 33 dari RI untuk seluruh indonesia

Menurut Iman Soepomo Undang-undang Kecelakaan tetap memakai prinsip resque professional, tetapi sudah lebih maju dibandingkan Ongevallen-Regelling. Undang-undang Kecelakaan mencakup kecelakaan yang menimpa buruh dalam hubungan kerja, yaitu kecelakaan yang ada hubungannya dengan hubungan kerja termasuk penyakit yang timbul sebagai akibat menjalankan pekerjaan di perusahaan, artinya seorang buruh yang menderita penyakit jabatan (occupational diseases) berhak atas ganti rugi ${ }^{7}$.

Untuk lebih memberikan perlindungan bagi buruh/pekerja maka diberlakukan Undang-undang Nomor 14 Tahun 1969 tentang Ketentuanketentuan Pokok Mengenai Tenaga Kerja. Undang-undang ini juga menjadi

${ }^{6}$ F.X. Djumialdji, Perjanjian Kerja, (Jakarta: Bumi Aksara, 1992), hlm. 63-64.

${ }^{7}$ Iman Soepomo, Op.cit, hlm.140. 
dasar hukum pengaturan jaminan sosial tenaga kerja khususnya Pasal 10 dan Pasal 15. Pasal 10 merumuskan bahwa :

Pemerintah membina perlindungan tenaga kerja yang mencakup:

a) norma keselamatan kerja;

b) norma kesehatan kerja dan hygiene perusahaan;

c) norma kerja; dan

d) pemberian ganti kerugian, perawatan, dan rehabilitasi dalam hal kecelakaan kerja.

Sedangkan Pasal 15 merumuskan bahwa: "pemerintah mengatur penyelenggaraan pertanggungan sosial dan bantuan sosial bagi tenaga kerja dan keluarganya". Dalam penjelasan pasal tersebut disebutkan bahwa:

Cara yang paling tepat ialah dengan mengadakan pertanggungan sosial yang dipikul oleh semua pihak yang kelak akan diatur oleh peraturan perundangan. Sudah selayaknya jika dalam badan dan lembaga yang menyelenggarakan pertanggungan sosial ini semua pihak turut duduk.

Jaminan dan bantuan sosial tersebut meliputi antara lain jaminan sakit, hamil, bersalin, hari tua, meninggal dunia, cacat dan, mengganggur bagi seluruh tenaga kerja termasuk tani dan nelayan.

Untuk melaksanakan ketentuan UU No. 14 Tahun 1969 khususnya Pasal 10 dan 15 maka diberlakukan Peraturan Pemerintah Nomor 33 Tahun 1977 tentang Asuransi Sosial Tenaga Kerja (ASTEK) dan Peraturan Pemerintah Nomor 34 Tahun 1977 tentang Perum ASTEK. Dengan demikian, pembayaran ganti kerugian menjadi tanggung jawab Perum ASTEK dan kemudian PT. ASTEK (Persero) berdasarkan pada ketentuan Peraturan Menteri Tenaga Kerja Nomor Per-05/MEN/1993 tentang Petunjuk Teknis Pendaftaran Kepesertaan, Pembayaran Iuran, Pembayaran Santunan, dan Pelayanan Jaminan Sosial Tenaga Kerja Pasal 1 angka 1 yang menyebutkan bahwa :"badan penyelenggara adalah PT. ASTEK (Persero)". Kemudian berdasarkan Peraturan Pemerintah Nomor 36 Tahun 1995 tentang Penetapan Badan Penyelenggara Program Jaminan Sosial Tenaga Kerja menjadi PT. Jamsostek (Persero). Jaminan yang diberikan menurut PP No. 33 Tahun 1977 dan PP No. 34 Tahun 1977 tidak hanya ganti kerugian karena kecelakaan kerja saja, tetapi meliputi pula jaminan kematian dan jaminan hari tua, yang dikenal dengan program jaminan kecelakaan kerja, jaminan kematian dan jaminan hari tua. Dengan demikian terjadi pergeseran pembayaran ganti kerugian, yang semula ditanggung langsung oleh pengusaha menjadi menggunakan mekanisme asuransi.

Pelaksanaan lebih lanjut Undang-undang No. 14 Tahun 1969 khususnya Pasal 10 dan 15 sekaligus memberikan dasar hukum yang kuat tentang jaminan sosial tenaga kerja maka diberlakukan Undang-undang Nomor 3 Tahun 1992 tentang Jaminan Sosial Tenaga Kerja dan Peraturan 
Pemerintah No. 14 Tahun 1993 tentang Penyelenggaraan Program Jaminan Sosial Tenaga Kerja. Undang-undang ini juga mencabut berlakunya Undangundang Kecelakaan tahun 1947 juncto Undang-undang No. 2 Tahun 1951. Dengan demikian hingga era reformasi sekarang ini dasar hukum pengaturan tentang Jaminan Sosial Tenaga Kerja adalah Undang-undang No. 3 Tahun 1992 beserta peraturan pelaksanaannya. Bahkan dengan berlakunya Undangundang Nomor 13 tahun 2003 tentang Ketenagakerjaan yang merupakan kebijakan umum di bidang ketenagakerjaan UU No. 3 Tahun 1992 tetap masih berlaku. Dalam Undang-undang No. 13 tahun 2003 pengaturan jaminan sosial tenaga tercantum dalam Pasal 99, yang berbunyi :

(1) Setiap pekerja/buruh dan keluarganya berhak untuk memperoleh jaminan sosial tenaga kerja.

(2) Jaminan sosial tenaga kerja sebagaimana dimaksud dalam ayat (1), dilaksanakan sesuai dengan peraturan perundang-undangan yang berlaku.

Dengan berlakunya Undang-undang Sistem Jaminan Sosial Nasional (UU No. 40 Tahun 2004) eksistensi jaminan sosial tenaga kerja berdasarkan Undang-undang No. 3 Tahun 1992 masih tetap diakui. Hal ini tersirat dalam Bab VIII Ketentuan Peralihan Pasal 52 ayat (1a), yang pada pokoknya mengatur bahwa Perusahaan Perseroan (Persero) Jaminan Sosial Tenaga Kerja (PT. Jamsostek) yang dibentuk dengan Peraturan Pemerintah No. 36 Tahun 1995 tentang Penetapan Badan Penyelenggara Program Jaminan Sosial Tenaga Kerja dan berdasarkan UU No. 3 Tahun 1992 tentang Jaminan Sosial Tenaga Kerja tetap berlaku sepanjang belum disesuaikan dengan Undang-undang No. 40 Tahun 2004. Meskipun sekarang telah berlaku Undang-undang Nomor 24 Tahun 2011 tentang Badan Penyelenggara Jaminan Sosial (BPJS) sebagai peraturan pelaksanaan dari Undang-undang No. 40 Tahun 2004 khususnya Pasal 5 ayat (1) dan Pasal 52, jaminan sosial tenaga kerja berdasarkan UU No. 3 Tahun 1992 tetap masih berlaku. Berdasarkan Bab XVII Ketentuan Peralihan Pasal 57 huruf d UU No. 24 Tahun 2011 dinyatakan bahwa dengan berlakunya Undang-undang ini Perusahaan Perseroan (Persero) Jaminan Sosial Tenaga Kerja (PT. Jamsostek) yang dibentuk dengan Peraturan Pemerintah No. 36 Tahun 1995 tentang Penetapan Badan Penyelenggara Program Jaminan Sosial Tenaga Kerja berdasarkan UU No. 3 Tahun 1992 tentang Jaminan Sosial Tenaga Kerja tetap melaksanakan kegiatan operasional penyelenggaraan program jaminan pemeliharaan kesehatan termasuk penambahan peserta baru sampai dengan beroperasinya Badan Penyelenggara Jaminan Sosial (BPJS) Kesehatan, dan begitu pula dengan program jaminan kecelakaan kerja, jaminan kematian, dan jaminan hari tua bagi pesertanya, termasuk penambahan peserta baru sampai dengan berubah menjadi Badan Penyelenggara Jaminan Sosial (BPJS) Ketenagakerjaan. BPJS Kesehatan 
mulai beroperasi menyelenggarakan program jaminan kesehatan pada tanggal 1 Januari 2014 (Pasal 60 ayat (1) UU No. 24 Tahun 2011) dan PT. Jamsostek (Persero) berubah menjadi BPJS Ketenagakerjaan pada tanggal 1 Januari 2014 (Pasal 62 ayat (1) UU No. 24 Tahun 2011). Pada saat berubahnya PT. Jamsostek (Persero) menjadi BPJS Ketenagakerjaan Peraturan Pemerintah No. 36 Tahun 1995 dicabut dan dinyatakan tidak berlaku lagi (Pasal 68 huruf a UU No. 24 Tahun 2011), dan pada saat mulai beroperasinya BPJS Ketenagakerjaan menyelenggarakan program jaminan kecelakaan kerja, jaminan hari tua, jaminan pensiun, dan jaminan kematian (paling lambat 1 Juli 2015), Undang-undang No. 3 Tahun 1992 tentang Jaminan Sosial Tenaga Kerja dicabut dan dinyatakan tidak berlaku lagi (Pasal 69 UU No. 24 Tahun 2011). Menurut berita dari Metrotvnews.com, Bandung bahwa Badan Penyelenggara Jaminan Sosial (BPJS) Kesehatan diresmikan bersama dengan BPJS Ketenagakerjaan, 31 Desember 2013, namun waktu beroperasinya berbeda, karena BPJS Ketenagakerjaan paling lambat berlaku efektif mulai 1 Juli 2015, sementara BPJS Kesehatan mulai 1 Januari $2014^{8}$.

Undang-undang No. 40 Tahun 2004 juncto UU No. 24 Tahun 2011 memperluas kemanfaatan program jaminan sosial menjadi 5 (lima) program, yaitu : jaminan kesehatan, jaminan kecelakaan kerja, jaminan hari tua, jaminan pensiun, dan jaminan kematian (Pasal 18 UU No. 40 Tahun 2004 dan Pasal 6 UU No. 24 Tahun 2011). Dengan peraturan perundangundangan baru ini nampak bahwa buruh/pekerja telah lebih terlindungi jika dilihat dari segi jenis-jenis program jaminan sosial tenaga kerja.

\section{Program-Program Jaminan Sosial Tenaga Kerja}

Sesuai dengan ketentuan Pasal 18 UU No. 40 Tahun 2004 tentang SJSN dan Pasal 6 UU No. 24 Tahun 2011 tentang BPJS maka programprogram jaminan sosial tenaga kerja meliputi program jaminan kesehatan, jaminan kecelakaan kerja, jaminan hari tua, jaminan pensiun, dan jaminan kematian. Tiga program yaitu program jaminan kecelakaan kerja, jaminan hari tua, jaminan kematian masih berpedoman pada ketentuan Pasal 8 sampai dengan Pasal 15 UU No. 3 Tahun 1992 tentang Jaminan Sosial Tenaga Kerja dan selambat-lambatnya pada 1 Juli 2015 BPJS Ketenagakerjaan beroperasi sesuai dengan ketentuan UU SJSN, maka seluruh pasal UU Jamsostek dicabut dan dinyatakan tidak berlaku lagi ${ }^{9}$.

\footnotetext{
${ }^{8}$ Lukman Diah Sari, "BPJS Ketenagakerjaan Harus Bisa Beroperasi Tahun Ini 2014" http://www.jamsostek.co.id/[21/02/2014].

${ }^{9} \mathrm{http}: / / \mathrm{www} . j \mathrm{amsosindonesia.com,} 2013$
} 


\section{a. Jaminan Kecelakaan Kerja (JKK)}

Jaminan kecelakaan kerja memberikan jaminan dan santunan yang berupa uang apabila tenaga kerja mengalami kecelakaan kerja. Kecelakaan kerja merupakan kecelakaan yang terjadi dalam hubungan kerja termasuk sakit yang diakibatkan karena kerja serta kecelakaan yang terjadi dalam perjalanan dari rumah ke tempat kerja dan kembali ke rumah (pulang kerja). Perihal ini Sentanoe Kertonegoro berpendapat :

Jaminan kecelakaan kerja (JK) memberikan penggantian biaya, ganti rugi, dan satunan bagi tenaga kerja yang mengalami kecelakaan atau sakit yang timbul dari dan dalam hubungan kerja. Penggantian biaya diberikan untuk mengganti biaya pengangkutan dan perawatan yang telah dikeluarkan oleh pengusaha. Ganti rugi diberikan untuk mengganti berkurangnya atau hilangnya kemampuan bekerja berpenghasilan berupa penggantian upah selama tenaga kerja tidak mampu bekerja. Sedangkan santunan diberikan untuk cacat tetap sebagian, cacat tetap total, atau meninggal dunia akibat kecelakaan atau sakit karena kerja ${ }^{10}$.

\section{b. Jaminan Kematian (JKM)}

Jaminan kematian adalah jaminan yang diberikan kepada keluarga ahli waris tenaga kerja yang meninggal bukan akibat kecelakaan kerja, guna meringankan beban keluarga dalam bentuk santunan kematian, biaya pemakaman, dan santunan berkala. Dalam hal manfaat jaminan kematian Penjelasan Umum Undang-undang No. 3 Tahun 1992, menyatakan sebagai berikut :

Tenaga kerja yang meninggal dunia bukan akibat kecelakaan kerja akan mengakibatkan terputusnya penghasilan, dan sangat berpengaruh pada kehidupan sosial ekonomi bagi keluarga yang ditinggalkan. Oleh karena itu, diperlukan jaminan kematian dalam upaya meringankan beban keluarga baik dalam bentuk biaya pemakaman maupun santunan berupa uang.

Sejalan dengan uraian di atas, Sentanoe Kertonegoro ${ }^{11}$ berpendapat:

JKM pada prinsipnya merupakan unsur komplementer dari JHT. Jika karena suatu sebab, tenaga kerja meninggal dunia sebelum hari tua (prematur death) maka saldo tabungannya masih rendah, dalam hal demikian, santunan JKM akan menambah saldo JHT sehingga dapat memberikan jumlah peninggalan yang cukup berarti bagi ahli warisnya.

\footnotetext{
${ }^{10}$ Sentanoe Kertonegoro, JPK Perlu Proses Panjang, Majalah ASTEK , Tahun IX, No. 3, Agustus 1993, hlm. 35.

${ }^{11}$ Ibid., hlm.35-36.
} 
Jaminan kematian pada prinsipnya bukan untuk mengganti jiwa tenaga kerja dengan santunan berupa uang, tetapi untuk membantu meringankan beban keluarga yang ditinggal mati oleh tenaga kerja dan dimaksudkan pula untuk mengganti sebagian dari sumber penghasilan yang hilang bagi ahli waris dari tenaga kerja yang meninggal dunia. Hal ini mengingat hilangnya jiwa seseorang karena meninggal dunia tidak mungkin dapat dinilai dengan uang, tetapi disamping itu resiko kematian merupakan resiko yang tidak bisa dielakan oleh setiap manusia.

\section{c. Jaminan Hari Tua (JHT)}

Jaminan hari tua (JHT) adalah jaminan yang memberikan kepastian penerimaan penghasilan yang diberikan sekaligus atau berkala pada saat tenaga kerja mencapai hari tua (usia 55 tahun) atau memenuhi persyaratan tertentu. Masalah JHT ini Sentanoe Kertonegoro ${ }^{12}$ berpendapat :

Jaminan hari tua (JHT) memberikan santunan pada saat tenaga kerja mencapai umur 55 tahun, mengalami cacat tetap dan total, meninggal dunia, meninggalkan Indonesia untuk tidak kembali lagi, atau mengalami PHK dengan masa kepesertaan setidaktidaknya lima tahun.

Arti penting jaminan hari tua bagi tenaga kerja dengan jelas diuraikan di dalam Penjelasan Umum UU No. 3 Tahun 1992, yaitu sebagai berikut :

Hari tua dapat mengakibatkan terputusnya upah karena tidak lagi mampu bekerja. Akibat terputusnya upah tersebut dapat menimbulkan kerisauan bagi tenaga kerja dan mempengaruhi ketentraman kerja sewaktu mereka masih bekerja, terutama bagi mereka yang penghasilannya rendah. Jaminan hari tua memberikan kepastian penerimaan penghasilan yang dibayarkan sekaligus dan atau berkala pada saat tenaga kerja mencapai usia 55 (lima puluh lima) tahun atau memenuhi persyaratan tertentu.

Jaminan hari tua pada prinsipnya memberikan manfaat berupa kepastian jaminan bagi kelangsungan hidup dimasa yang akan datang, terutama setelah tenaga kerja yang bersangkutan tidak produktif lagi. Perihal kemanfaatan jaminan hari tua Sentanoe Kertonegoro ${ }^{13}$ berpendapat:

Kemanfaatan JHT berupa saldo tabungan pada rekening tenaga kerja masing-masing yang terdiri dari pemupukan iuran peserta tenaga kerja masing-masing yang terdiri dari pemupukan iuran beserta bunganya. Selain itu, JHT yang pada hakikatnya juga merupakan dana bersama (mutual fund) mendapat bagian dari surplus hasil usaha badan penyelenggara setiap tahun.

\footnotetext{
${ }^{12}$ Ibid., hlm.35.

${ }^{13} \mathrm{Ibid}$.
} 


\section{d. Jaminan Kesehatan (JK)}

Semula jaminan kesehatan bagi buruh/pekerja merupakan salah satu program yang diselenggarakan oleh PT Jamsostek yang bernama jaminan pemeliharaan kesehatan (JPK), dan sekarang dengan beroperasinya BPJS Kesehatan menjadi program yang diselenggarakan oleh BPJS Kesehatan sejak tanggal 1 Januari 2014 (Pasal 60 ayat (1) UU No. 24 Tahun 2011). Jaminan kesehatan merupakan salah satu jenis program jaminan sosial nasional yang diatur dalam UU No. 40 Tahun 2004 tentang SJSN.

Jaminan kesehatan adalah jaminan berupa perlindungan kesehatan agar peserta memperoleh manfaat pemeliharaan kesehatan dan perlindungan dalam memenuhi kebutuhan dasar kesehatan yang diberikan kepada setiap orang yang telah membayar iuran atau iurannya dibayar oleh pemerintah (Pasal 1 angka (1) Perpres Nomor 12 Tahun 2013 tentang Jaminan Kesehatan). Manfaat jaminan kesehatan bersifat pelayanan kesehatan perorangan, mencakup pelayanan promotif, preventif, kuratif, dan rehabilitasi termasuk pelayanan obat dan bahan medis habis pakai sesuai dengan kebutuhan medis yang diperlukan (Pasal 20 Perpres No. 12 Tahun 2013). Berdasarkan Pasal 22 Perpres No. 111 Tahun 2013 tentang Perubahan Atas Perpres No. 12 Tahun 2013, pelayanan kesehatan yang dijamin terdiri atas :

1. Pelayanan kesehatan tingkat pertama, meliputi pelayanan kesehatan nonspesialistik yang mencakup: administrasi pelayanan; pelayanan promotif dan preventif; pemeriksaan, pengobatan, dan konsultasi medis; tindakan medis nonspesialistik, baik operatif maupun nonoperatif; pelayanan obat dan bahan medis habis pakai; transfusi darah sesuai dengan kebutuhan medis; pemeriksaan penunjang diagnostik laboratorium tingkat pertama; dan rawat inap tingkat pertama sesuai dengan indikasi medis;

2. Pelayanan kesehatan rujukan tingkat lanjutan, yang meliputi: administrasi pelayanan; pemeriksaan, pengobatan, dan konsultasi spesialistik oleh dokter spesialis dan subspesialis; tindakan medis spesialistik, baik bedah maupun nonbedah sesuai dengan indikasi medis; pelayanan obat dan bahan medis habis pakai; pelayanan penunjang diagnostik lanjutan sesuai dengan indikasi medis; rehabilitasi medis; pelayanan darah; pelayanan kedokteran forensik klinik; pelayanan jenazah pada pasien yang meninggal di fasilitas kesehatan; perawatan inap nonintensif; dan perawatan inap di ruang intensif;

3. Pelayanan kesehatan lain yang ditetapkan oleh menteri; dan

4. Peserta berhak mendapatkan pelayanan berupa alat kesehatan. 


\section{e. Jaminan Pensiun (JP)}

Jaminan pensiun ini merupakan salah satu jenis program jaminan sosial nasional yang diatur dalam UU No. 40 Tahun 2004 tentang Sistem Jaminan Sosial Nasional (SJSN). Pengertian jaminan pensiun (JP) menurut naskah akademik SJSN adalah pembayaran berkala jangka panjang sebagai substitusi dari penurunan/hilangnya penghasilan karena peserta mencapai usia tua (pensiun), mengalami cacat total permanen, atau meninggal dunia. ${ }^{14}$ Tujuan penyelenggaraan jaminan pensiun adalah untuk mempertahankan derajat kehidupan yang layak saat peserta kehilangan atau berkurang penghasilannya karena memasuki usia pensiun atau mengalami cacat total tetap (Pasal 39 ayat (2) UU No. 40 Tahun 2004 tentang SJSN). Jadi pada pokoknya Jaminan pensiun adalah jaminan yang memberikan kepastian penerimaan penghasilan yang diberikan selama tenaga kerja pensiun.

\section{Penutup}

Pengaturan jaminan sosial tenaga kerja sudah dimulai sejak zaman penjajahan pemerintahan Hindia Belanda, yaitu dalam KUH Perdata dan Peraturan Kecelakaan atau Ongevallen-Regelling 1939, namun baik dalam KUH Perdata maupun Peraturan Kecelakaan atau Ongevallen-Regelling Tahun 1939 belum memberikan jaminan perlindungan hukum bagi buruh/pekerja di bidang jaminan sosial tenaga kerja. Baru pada masa kemerdekaan Republik Indonesia terutama setelah diberlakukannya peraturan perundangan dibidang jaminan sosial tenaga kerja, buruh/pekerja memperoleh jaminan perlindungan hukum di bidang jaminan sosial tenaga kerja. Program-programnyapun tidak hanya jaminan ganti-rugi karena kecelakaan kerja saja, tetapi meliputi program jaminan kecelakaan kerja (JKK), program jaminan kematian (JKM), program jaminan hari tua (JHT), dan program jaminan pemeliharaan kesehatan (JPK). Kemudian kemanfaatan program jaminan sosial tenaga kerja semakin bertambah dengan adanya jaminan pensiun (JP) oleh Undang-undang Sistem Jaminan Sosial Nasional (UU No. 40 Tahun 2004) juncto Undang-undang Nomor 24 Tahun 2011 tentang Badan Penyelenggara Jaminan Sosial (BPJS). Jaminan kecelakaan kerja memberikan jaminan dan santunan yang berupa uang apabila tenaga kerja mengalami kecelakaan kerja. Jaminan kematian adalah jaminan yang diberikan kepada keluarga ahli waris tenaga kerja yang meninggal bukan akibat kecelakaan kerja, guna meringankan beban keluarga

\footnotetext{
14“Program Jaminan Pensiun", 2013.http:

//www.jamsosindonesia.com/sjsn/Program/program_jaminan_pensiun
} 
dalam bentuk santunan kematian dan biaya pemakaman. Jaminan hari tua adalah jaminan yang memberikan kepastian penerimaan penghasilan yang diberikan sekaligus atau berkala pada saat tenaga kerja mencapai hari tua (usia 55 tahun) atau memenuhi persyaratan tertentu. Jaminan pemeliharaan kesehatan dimaksudkan untuk meningkatkan produktivitas tenaga kerja sehingga dapat melaksanakan tugas sebaik-baiknya dan merupakan upaya kesehatan dibidang penyembuhan (kuratif). Jaminan pensiun adalah jaminan yang memberikan kepastian penerimaan penghasilan yang diberikan selama tenaga kerja pensiun.

\section{Daftar Pustaka}

\section{A. Buku}

Asikin, Zainal, dkk., 2006, Dasar-dasar Hukum Perburuhan, Jakarta: Radja Grafindo Persada.

Djumialdji, F.X., 1992. Perjanjian Kerja, Jakarta: Bumi Aksara.

Hakim, Abdul, 2003. Pengantar Hukum Ketenagakerjaan Indonesia: Berdasarkan UU No, 13 Tahun 2003, Bandung: Citra Aditya Bakti.

Husni, Lalu, 2007. Pengantar Hukum Ketenagakerjaan Indonesia, Jakarta: Radja Grafindo Persada.

Maimun, 2004. Hukum Ketenagakerjaan, Jakarta: Pradnya Paramita.

Muharam, Hidayat, 2006. Hukum Ketenagakerjaan Serta Pelaksanaannya di Indonesia, Bandung: Citra Aditya Bakti.

Ramli, Lanny, 1997. Jaminan Sosial Tenaga Kerja di Indonesia, Surabaya: Airlangga University Press.

Soedarjadi, 2008. Hukum Ketenagakerjaan, Yogyakarta: Pustaka Yustisia.

Soepomo, Iman, 2003. Pengantar Hukum Perburuhan, Jakarta: Djambatan.

\section{B. Majalah}

Sentanoe Kertonegoro, "JPK Perlu Proses Panjang", Majalah ASTEK, Tahun IX, No. 3, Agustus 1993.

\section{Peraturan Perundang-undangan}

Kitab Undang-undang Hukum Perdata.

Undang-Undang Dasar Negara Republik Indonesia Tahun 1945.

Undang-undang Nomor 3 Tahun 1992 tentang Jaminan Sosial Tenaga Kerja

Undang-undang Nomor 13 Tahun 2003 Tentang Ketenagakerjaan.

Undang-undang No. 40 Tahun 2004 tentang Sistem Jaminan Sosial Nasional. 
Undang-undang Nomor 24 Tahun 2011 tentang Badan Penyelenggara Jaminan Sosial (BPJS).

Peraturan Pemerintah No. 14 Tahun 1993 tentang Penyelenggaraan Program Jaminan Sosial Tenaga Kerja.

Peraturan Presiden Nomor 12 Tahun 2013 tentang Jaminan Kesehatan.

Peraturan Presiden No. 111 Tahun 2013 tentang Perubahan Atas Peraturan Presiden Nomor 12 Tahun 2013 tentang Jaminan Kesehatan.

Peraturan Badan Penyelenggara Jaminan Sosial Kesehatan Nomor 1 Tahun 2014 tentang Penyelenggaraan Jaminan Kesehatan.

\section{Website}

http://www.jamsostek.co.id.http://www.jamsosindonesia.com. 